\title{
R \& D Attention and Profit Performance-An Empirical Study on Listed Companies in China's Electric Power and Electrical Industries
}

\author{
Shiyin Jing ${ }^{1}$, Yanbin $\mathrm{Li}^{1, *}$ and Yulong Sun ${ }^{2,3}$ \\ 1 School of Economics and Management, North China Electric Power University, Beijing 102206, China; \\ jingshiyin@126.com \\ 2 China Academy of Corporate Governance, Nankai University, Tianjin 300071, China; sunyul1995@163.com \\ 3 Business School, Nankai University, Tianjin 300071, China \\ * Correspondence: liyb@ncepu.edu.cn
}

Citation: Jing, S.; Li, Y.; Sun, Y. R \& D Attention and Profit Performance —An Empirical Study on Listed Companies in China's Electric Power and Electrical Industries.

Sustainability 2021, 13, 8387. https:// doi.org/10.3390/su13158387

Academic Editor: Donato Morea

Received: 21 May 2021

Accepted: 24 July 2021

Published: 27 July 2021

Publisher's Note: MDPI stays neutral with regard to jurisdictional claims in published maps and institutional affiliations.

Copyright: (c) 2021 by the authors. Licensee MDPI, Basel, Switzerland. This article is an open access article distributed under the terms and conditions of the Creative Commons Attribution (CC BY) license (https:/ / creativecommons.org/licenses/by/ $4.0 /)$.

\begin{abstract}
The electric power and electric industries are basic and strategic emerging industries in China's national economy. Based on the data of listed companies in China's electric power and electric industries from 2015 to 2019, this paper empirically studies the impact of research and development $(\mathrm{R} \& \mathrm{D})$ attention on corporate profitability. The results show that attention to $R$ \& D by listed companies in electric power and electric industries will significantly improve enterprise's profit performance, and this kind of effect has yearly heterogeneity. From 2015 to 2017, R \& D attention gradually improved the profit performance of enterprises, but the profit spillover effect of $\mathrm{R} \& \mathrm{D}$ investment in recent years needs to be further strengthened. Further study found that $\mathrm{R}$ $\& D$ attention has a significant effect on corporate profitability in the private enterprise group, the R \& D attention of state-owned enterprises and R \& D structure adjustment should be paid more attention; R \& D investment can significantly improve the profitability of the electrical industry, but the promotion effect was relatively slow in recent years, and R \& D investment has a significant effect on the profitability of listed companies in the electric power industry. Although the promotion effect is not obvious, it shows a steady improvement trend. After variable and model replacement, the empirical regression conclusion of this paper is still robust. The results of this paper help to deepen the understanding of the stage characteristics of the impact of $R \& D$ attention on profit performance, and it is of great significance to optimize the efficiency of $R \& D$ investment and pay attention to the adjustment of R \& D structure in the electric power and electrical industries.
\end{abstract}

Keywords: R \& D attention; profit performance; electric power industry; electrical industry

\section{Introduction}

Economic and social development is inseparable from the improvement of the level of science and technology, and innovation is the first driving force to promote the progress of science and technology. The R \& D innovation of enterprises is related to their own survival, competitiveness and sustainable development and ultimately has an impact on the economic level and sustainable competitiveness of the whole country. The success of R \& D innovation can bring the favor of capital and capital for enterprises and win rapid growth and excess returns. In today's increasingly competitive market economy, $\mathrm{R} \& \mathrm{D}$ innovation has gradually become the core element of the sustainable growth and invincible competition of enterprises and countries, which has attracted more and more attention of all countries. At present, the total amount of R \& D investment of Chinese enterprises is increasing year by year, but the intensity of R \& D investment, the efficiency of input-output and the importance of $\mathrm{R} \& \mathrm{D}$ are not optimistic. On the whole, they attach importance to technological innovation and scale expansion but do not attach importance to the development of high-end innovation. In recent years, as China's economy gradually 
shifted from a stage of high-speed growth to a stage of high-quality development, more and more enterprises focused on technological innovation and stimulated the vitality of research and innovation. Innovation has gradually become an important way to promote economic and social development and enhance corporate vitality. Research on the economic consequences of corporate $\mathrm{R} \& \mathrm{D}$ has gradually become important topics in the academic field and the practical world.

The electric power industry is a basic industry in the national economy, and power innovation has been an important part of the development of the industry. In September 2020, the State Grid Corporation of China held a scientific and technological innovation conference, which emphasized the need to increase R \& D investment, enhance original innovation capabilities, overcome difficulties in mastering core technologies and promote the transformation of the grid system to the energy Internet. What is more, the electrical industry is closely related to the power industry. In recent years, the R \& D investment and growth rate have been at the forefront of China's overall industry. The production of various power grid construction related generator units and transmission and distribution equipment has shown rapid localization speed. What kind of economic consequences does the huge investment in R \& D of China's electric power and electrical industries produce and whether it improves the profitability of enterprises is the focus of this paper.

The purpose of this paper is to use the data of Listed Companies in China's electric power industry and electric industry from 2015 to 2019 to explore the impact of R \& D attention on corporate profitability through theoretical analysis and empirical research. First of all, this paper intends to use the method of year-on-year regression to preliminarily explore whether the $\mathrm{R} \& \mathrm{D}$ attention of listed companies significantly improved the profit performance of enterprises and explore whether this effect has year heterogeneity, so as to provide guiding evidence for the R \& D investment of China's power industry and electrical industry. Secondly, this paper intends to explore and excavate the heterogeneity of R \& D emphasis in power industry and electrical industry under different property rights, so as to help decision-making departments find $\mathrm{R} \& \mathrm{D}$ investment and profit performance under different property rights, so as to formulate reasonable policies and incentive mechanisms. Finally, this paper uses different models and variable measures to test the correctness and universality of this study.

The contributions of this paper are mainly reflected in these aspects: First, the existing literature research on $\mathrm{R} \& \mathrm{D}$ investment and profit performance is mainly concentrated on the research of high-tech industries, pharmaceutical manufacturing and information technology industries (Guo et al., 2020; Xu et al., 2020; Yang et al., 2019) [1-3] or uses intermediate variables to explore the relationship between $\mathrm{R} \& \mathrm{D}$ investment and operating performance (Tebourbi et al., 2020; Wu et al., 2016) [4,5]. Previous studies mostly carried out research from the perspective of $R \& D$ investment. From the perspective of resource dependence theory, this paper considers the performance of $R \& D$ attention, which helps to enrich the theory and literature of resource theory. The research conclusions of this paper help to expand the research field of $\mathrm{R} \& \mathrm{D}$ attention and make up for the gap of existing literature. Secondly, in the further study, this paper conducts a group study on the property right nature and industry nature of Chinese enterprises and gets the corresponding research conclusions according to the nature and industry of different enterprises. This study helps to clarify the mechanism and industry heterogeneity of $R$ \& D performance in China's power and electrical industry. Thirdly, this paper uses the method of year-on-year regression to explore the heterogeneity of years and stages and discusses the relationship between $\mathrm{R} \& \mathrm{D}$ attention and corporate profitability in different stages of the electric power and electric industry. This study helps to deepen the understanding of the periodic impact of $R$ \& $D$ attention on earnings performance of the electric and electric industry by Chinese government policies and international environment.

This paper mainly discusses the impact path of $R$ \& $D$ attention on profit performance of China's power industry and electrical industry, explores the impact differences in different years and finds the heterogeneity of $R \& D$ attention of state-owned enterprises 
and non-state-owned enterprises according to different property rights and then puts forward a reasonable incentive mechanism. The rest of this paper is structured as follows: the second part is the literature review and hypothesis; the third part is the experimental design; the fourth part is the analysis of the experimental results, and the fifth part is the research conclusion.

\section{Literature Review and Hypothesis}

In recent years, as $\mathrm{R} \& \mathrm{D}$ innovation has attracted worldwide attention; scholars have conducted a lot of research on the economic consequences of $\mathrm{R} \& \mathrm{D}$ investment in the academic field. Some scholars have studied the relationship between R \& D investment and enterprise performance under different sample characteristics. Aboody and Lev (1998) conducted a study on American chemical enterprises and found that R \& D investment has a lagging effect on performance [6]. Roberts (1995) studied the relationship between $R$ $\& \mathrm{D}$ innovation and the growth rate of sales revenue based on the samples of high-tech industries in the United States and Japan and found that R \& D investment would significantly improve the profitability of enterprises [7]. Lee et al. (2017) studied the relationship between R \& D investment and corporate performance of listed companies in South Korea by grouping companies according to their size and found that SMEs and KOSDAQ were more valuable for investment [8]. From the perspective of third-party variables, some scholars excavated the influence mechanism of $\mathrm{R} \& \mathrm{D}$ investment on enterprise performance. Vivarelli (2003) found that R \& D investment was indeed significantly positively correlated with enterprise performance, and the ownership structure and innovation strategy of an enterprise would affect its R \& D activities [9]. Woo et al. (2020) distinguished large and medium-sized enterprises, analyzed the important factors affecting the company's performance from the perspective of small and medium-sized enterprises, and put forward reasonable $\mathrm{R} \& \mathrm{D}$ investment direction for the company [10]. Inconsistent with the above results, there are also scholars who hold opposite views. Brown (1998) studied samples from Japan and some European and American countries and found that the growth range of sales income could not match the increase of R \& D income [11].

In addition, some scholars have conducted research on the relationship between $R$ \& $\mathrm{D}$ and performance in different scenarios. Teirlink (2017) uses the research data of SMEs from 2010 to 2013 and uses the method of qualitative comparison to think that managers of SMEs should pay more attention to the $\mathrm{R} \& \mathrm{D}$ method of functional structure in the process of strategic R \& D, so as to improve financial performance [12]. Lee et al. (2011) focused on the R \& D performance of small and medium-sized service enterprises in South Korea and found that the existence of $R$ \& D management had a negative impact on the company's performance [13]. Dong et al. (2010) empirically tested the impact of $\mathrm{R} \& \mathrm{D}$ and patents on the financial performance of venture enterprises by using random and fixed effect models and found that $\mathrm{R} \& \mathrm{D}$ investment will play an important role in the patent situation [14]. Alam et al. (2019) studied the impact of R \& D investment on enterprise environmental performance by using enterprise data of G6 countries from 2004 to 2016 and found that higher R \& D investment will bring environmental performance [15]. Lee et al. (2015), from the perspective of resource-based view, studied the impact of green R \& D investment on Ecological Innovation and its impact on environmental and financial performance and believed that green $\mathrm{R} \& \mathrm{D}$ can play a role in improving ecological innovation and reducing carbon emissions [16]. Bernile et al. (2016), from the perspective of the board of directors, found that the diversification of the board of directors will enhance the sustainable investment of enterprises in $R \& D$, and the diversification of the board of directors will affect the policies and risks of enterprises [17]. Baumann et al. (2016) analyzed the relationship between R \& D, innovation and productivity and found that $\mathrm{R} \& \mathrm{D}$ innovation can improve labor productivity in both micro enterprises and large enterprises, and hunger can hardly bear to improve the production capacity of enterprises [18]. Yigitcanalar et al. (2017) studied the driving effect of corporate innovation on economic growth in Brazil and Australia and believed that the government's adoption 
of direct incentives can significantly improve the innovation ability of enterprises, and tax incentives and infrastructure development incentives are more likely to be welcomed by enterprises [19]. Song et al. (2018) used the samples of Chinese manufacturing enterprises to study the relationship between environmental regulations, $R$ \& D efficiency and enterprise profits and found that the quality of employees will deeply affect the R \& D efficiency of enterprises and then affect the profits of enterprises [20].

Ferraris et al. (1997) studied the impact of external R \& D on enterprise innovation performance and believed that if the enterprise has excellent knowledge management ability, it can better manage external knowledge and combine it with internal knowledge, so as to improve enterprise innovation performance [21]. According to Ferraris' point of view, combined with the theory of resource dependence, this paper holds that the development of enterprises is inseparable from all kinds of resources, and R \& D investment often brings the output of intangible assets such as patents, which often provides all kinds of scarce resources for the development of enterprises and reduces all kinds of costs in the production process. This paper argues that $\mathrm{R} \& \mathrm{D}$ attention will significantly improve the profitability of listed companies.

Combined with the aforementioned theoretical literature review, this paper discusses the economic impact of $\mathrm{R} \& \mathrm{D}$ attention in the power and electrical industries under the background of China's economic transformation based on the sample of listed companies in China's electric power industry and electrical industry and puts forward Hypothesis 1.

Hypothesis 1 (H1). Attention on $R \& D$ will significantly improve the earnings performance of listed companies in China's power and electrical industries.

Some scholars believe that privatization will improve the operating efficiency of enterprises. Megginson and Netter (2001) studied the major economies in the world and found that privatization can improve enterprise performance [22]. Li and Lee (2019) used Fama and Macbeth cross-sectional regression to analyze the Chinese samples with missing non-R \& D expenditure from 2007 to 2018 and found that the effects of investment and state-owned property rights are more significant in R \& D active enterprises [23]. From the perspective of privatization of state-owned enterprises, Saffar (2013) found that privatized shareholders pursue profit maximization and have higher awareness of risk taking, so privatized enterprises have higher motivation and creativity in research and development [24]. Chen et al. (2019) discussed the difference in investment frequency between private and state-owned enterprises from the perspective of dynamic $R$ \& $D$ investment [25]. On the basis of the above analysis, aiming at the theoretical differences between private enterprises and state-owned enterprises, this paper puts forward research hypothesis 2 .

Hypothesis 2 (H2). The degree of attention on research and development of listed companies in the private power and electrical industries has a more significant effect on the improvement of business performance.

The operation of an enterprise will be affected by internal governance and the external environment of the company. Internal factors mainly include enterprise size and ownership structure, while external factors include national policies and industry level. Han et al. (2019) for the sample of Chinese financial enterprises, from the perspective of internal governance, found that investment scale and investment efficiency will affect the operating income of the financial industry [26]. Jia and Lin (2021) studied the impact of cross subsidies on economic performance and social performance from the perspective of power industry and found that canceling cross subsidies will have a positive impact on economic performance but a negative impact on carbon dioxide emission reduction, industrial structure and social welfare [27]. Oh (2019) analyzed the ecological efficiency of South Korea's state-owned, affiliated and small and medium-sized power generation enterprises by using the method of data envelopment analysis; found that the ecological efficiency of 
small and medium-sized enterprises, listed companies and subsidiaries of large companies was higher in turn and put forward policy suggestions to encourage and support small and medium-sized enterprises [28]. Stefko et al. (2019) studied the financial situation of the whole electrical engineering industry in Slovakia by using the teller model, Springate model and aspect global rating model and analyzed the competitiveness of enterprises to reflect the performance of enterprises [29]. Sellitto et al. (2019) used structural equation model to analyze the effectiveness of green strategy, green innovation, green operation externality management and green operation information management on the competition of 70 companies in the electronic and electrical industry in Brazil and found that green strategy and green innovation have a greater impact on the industrial competitiveness [30]. In view of the theoretical differences between the electric power industry and the electrical industry, this paper puts forward research hypothesis 3 .

Hypothesis 3 (H3). Compared with the power industry, the $R \mathcal{E} D$ attention of Listed Companies in the electrical industry has a more significant effect on the improvement of business performance.

\section{Experimental Design}

\subsection{Samples and Data}

In this paper, the listed companies in the electric power and electrical industries in the A share market of Shenzhen Stock Exchange and Shanghai Stock Exchange from 2015 to 2019 are selected as the research data. The R \& D data, financial status and operation data of initial listed companies are from China stock market accounting research (CSMAR) economic database. After sorting and screening, a total of 1410 research samples were obtained, including 341 samples from the electric power industry and 1069 samples from the electrical industry. The annual sample data from 2015 to 2019 were 250, 260, 289, 298 and 313, respectively. See Table 1 for detailed data samples in this paper.

Table 1. Overview of data samples.

\begin{tabular}{ccccccc}
\hline \multirow{2}{*}{ Industry } & \multicolumn{5}{c}{ Year } & \multirow{2}{*}{ Total } \\
\cline { 2 - 5 } & $\mathbf{2 0 1 5}$ & $\mathbf{2 0 1 6}$ & $\mathbf{2 0 1 7}$ & $\mathbf{2 0 1 8}$ & $\mathbf{2 0 1 9}$ & \\
\hline Electric power industry & 64 & 65 & 70 & 70 & 72 & 341 \\
Electrical industry & 186 & 195 & 219 & 228 & 241 & 1069 \\
Total & 250 & 260 & 289 & 298 & 313 & 1410 \\
\hline
\end{tabular}

\subsection{Variable Selection and Explanation}

The explained variable studied in this paper is the profit effect of electric power and electrical industries. In the existing literature, the indicators that can be used to measure profitability include return on equity (ROE), return on assets (ROA), Tobin $Q$ value, and the Boston matrix method adopted by He, Sun et al. (2019) [31]. Considering the above methods and the characteristics of data samples, this paper adopts ROE, ROA and re-measured ROE dummy variables as the explained variables in the empirical study.

The explanatory variable in this study is the degree of $R$ \& $D$ attention, and annual $R$ \& $D$ investment is used as the measurement value of the degree of $R \& D$ attention. At present, $R$ \& D investment is mainly measured by absolute value of $R$ \& $D$ investment (Zhang et al., 2015) [32], ratio of R \& D investment to operating income (Liu et al., 2015) [33] and ratio of R \& D personnel to enterprise personnel (Xu et al., 2018) [34]. Considering that the power and electrical industries studied in this paper have high maturity and application practice, the logarithm of absolute value of $R \& D$ investment is adopted as the index to measure the degree of $\mathrm{R} \& \mathrm{D}$ attention. Total assets, debt paying ability, surplus reserve, capital preservation and corporate goodwill used in this study are respectively represented by Asset, LEV, SR, RCA and GW, while operating sustainability variables added in the robustness test are represented by SGR. The variable definitions and explanations in this paper are shown in Table 2. 
Table 2. Variable definitions and explanations.

\begin{tabular}{|c|c|c|c|}
\hline $\begin{array}{l}\text { Variable } \\
\text { Categories }\end{array}$ & $\begin{array}{l}\text { Variable } \\
\text { Symbols }\end{array}$ & Variable Names & Variable Definitions \\
\hline \multirow{3}{*}{ Explained variable } & ROE & Earnings Performance & $\begin{array}{l}\text { Annual return on net assets of listed companies in the electric } \\
\text { power and electrical industries, the percentage of the } \\
\text { company's after tax profit divided by its net assets; }\end{array}$ \\
\hline & ROE1 & Earnings Performance_1 & $\begin{array}{l}\text { The dummy variable of annual return on equity of listed } \\
\text { companies is } 1 \text { or } 0 ;\end{array}$ \\
\hline & $\mathrm{ROA}$ & Earnings Performance_2 & $\begin{array}{l}\text { Annual return on assets of listed companies in the electric } \\
\text { power and electrical industries; }\end{array}$ \\
\hline $\begin{array}{l}\text { Explanatory } \\
\text { variables }\end{array}$ & $\mathrm{RM}$ & R \& D Attention & $\begin{array}{l}\text { Ln (annual R \& D investment of the listed companies), if the } \\
\text { annual R \& D investment of the company is zero, the value is } \\
\text { assigned to } 0 ;\end{array}$ \\
\hline Test variables & SGR & Business Sustainability & $\begin{array}{l}\text { Sustainable growth rate of listed companies: return on net } \\
\text { assets } \times \text { retained earnings } /(1 \text {-return on net assets } \times \\
\text { retained earnings); }\end{array}$ \\
\hline \multirow{5}{*}{ Control variables } & ASSET & Total assets & $\begin{array}{c}\text { The logarithm value of the listed companies' year-end } \\
\text { total assets; }\end{array}$ \\
\hline & LEV & Debt Paying Ability & Annual asset-liability ratio of the listed companies; \\
\hline & SR & Surplus Reserves & $\begin{array}{l}\text { The logarithm value of the annual surplus reserve of the listed } \\
\text { companies; if the annual surplus reserve of the company is zero, } \\
\text { SR is assigned to 0; }\end{array}$ \\
\hline & RCA & Capital Preservation & $\begin{array}{c}\text { Rate of capital preservation and appreciation of } \\
\text { listed companies; }\end{array}$ \\
\hline & GW & Company Reputation & The logarithm of the net goodwill of a listed company. \\
\hline
\end{tabular}

\subsection{Model Design}

In order to verify the research hypothesis of this paper, considering that the panel data can analyze the relationship between variables from the perspectives of time and individuals, this paper establishes a panel regression model (1) of R \& D attention and profitability:

$$
\mathrm{ROE}_{\mathrm{i}, \mathrm{t}}=\alpha_{1}+\beta_{1}{ }^{*} \mathrm{RM}_{\mathrm{i}, \mathrm{t}}+\beta_{2}{ }^{*} \mathrm{ASSET}_{\mathrm{i}, \mathrm{t}}+\beta_{3}{ }^{*} \mathrm{LEV}_{\mathrm{i}, \mathrm{t}}+\beta_{4}{ }^{*} \mathrm{SR}_{\mathrm{i}, \mathrm{t}}+\beta_{5}{ }^{*} \mathrm{RCA}_{\mathrm{i}, \mathrm{t}}+\beta_{6}{ }^{*} \mathrm{GW}_{\mathrm{i}, \mathrm{t}}+\varepsilon
$$

At the same time, considering the regression heterogeneity of the electric power and electrical industries in different years, this paper adopts the method of regression year by year based on the annual data and establishes the cross-section regression model (2) for 2015-2019 successively as follows:

$$
\mathrm{ROE}=\alpha_{1}+\beta_{1}{ }^{*} \mathrm{RM}+\beta_{2}{ }^{*} \mathrm{ASSET}+\beta_{3}{ }^{*} \mathrm{LEV}+\beta_{4}{ }^{*} \mathrm{SR}+\beta_{5}{ }^{*} \mathrm{RCA}+\beta_{6}{ }^{*} \mathrm{GW}+\varepsilon
$$

In order to test the robustness of the empirical regression in this paper, this paper replaces and reconstructs the variable dimension and model dimension, respectively, and establishes the robustness test model (3) and model (4), respectively:

$$
\begin{array}{r}
\mathrm{ROA}_{\mathrm{i}, \mathrm{t}} \text { or } \mathrm{ROE}_{\mathrm{i}, \mathrm{t}}=\alpha_{1}+\beta_{1}{ }^{*} \mathrm{RM}_{\mathrm{i}, \mathrm{t}}+\beta_{2}{ }^{*} \mathrm{ASSET}_{\mathrm{i}, \mathrm{t}}+\beta_{3}{ }^{*} \mathrm{LEV}_{\mathrm{i}, \mathrm{t}}+\beta_{4}{ }^{*} \mathrm{SR}_{\mathrm{i}, \mathrm{t}}+\beta_{5}{ }^{*} \mathrm{RCA}_{\mathrm{i}, \mathrm{t}}+\beta_{6}{ }^{*} \mathrm{GW}_{\mathrm{i}, \mathrm{t}}+\beta_{7}{ }^{*} \mathrm{SGR}_{\mathrm{i}, \mathrm{t}}+\varepsilon \\
\text { Probit or Logit }\left(\mathrm{ROE}_{\mathrm{i}, \mathrm{t}}\right)=\alpha_{1}+\beta_{1}{ }^{*} \mathrm{RM}_{\mathrm{i}, \mathrm{t}}+\beta_{2}{ }^{*} \mathrm{ASSET}_{\mathrm{i}, \mathrm{t}}+\beta_{3}{ }^{*} \mathrm{LEV}_{\mathrm{i}, \mathrm{t}}+\beta_{4}{ }^{*} \mathrm{SR}_{\mathrm{i}, \mathrm{t}}+\beta_{5}{ }^{*} \mathrm{RCA}_{\mathrm{i}, \mathrm{t}}+\beta_{6}{ }^{*} \mathrm{GW}_{\mathrm{i}, \mathrm{t}}+\varepsilon
\end{array}
$$
$\beta_{6}$ is 0 .

It should be noted that in Model (3), when the explained variable is ROA, the value

\section{Analysis of Experimental Results}

In the part of empirical results analysis, this paper first makes a descriptive statistical analysis of the research data. Considering the pairwise correlation and multicollinearity of variables, Pearson correlation analysis and VIF test were performed. In the basic regression 
part, referring to the model design, the year-on-year regression and panel mixed OLS regression tests were carried out, respectively, and the BP-LM test and F test were carried out before the mixed OLS regression. In the further study, the division of property rights and industry groups are discussed. Finally, the robustness test is carried out by using explained variable replacement and model replacement (logit, probit model).

\subsection{Descriptive Statistics}

Table 3 is the descriptive statistical analysis results of each variable in this study. As the variable explained in this paper, the minimum value of profitability (ROE) is -60.153 , and the maximum value is 0.983. Meanwhile, the median and average value is 0.069 and -0.001 , respectively, which indicates that the profitability of each company/year in the electric power and electrical industries selected in this paper has a great degree of differentiation. Considering the data of the explanatory variable RM in this paper, the median, mean, 25-quantile and 75-quantile of RM are 17.924, 17.933, 17.209 and 18.972, respectively, which are all relatively close, indicating that the annual $\mathrm{R} \& \mathrm{D}$ investment of each company is relatively stable. In this paper, except for corporate goodwill (GW) and test variable business sustainability (SGR), the median, average, 25th and 75th percentiles of total assets (asset), debt paying ability (Lev), surplus reserve (SR) and capital preservation (RCA) are close to each other. It shows that the selection of non-experimental variables is reasonable.

Table 3. Descriptive statistical analysis.

\begin{tabular}{ccccccccc}
\hline Stats & ROE & RM & ASSET & LEV & SR & RCA & GW & SGR \\
\hline Mean & -0.001 & 17.933 & 22.382 & 0.464 & 18.426 & 1.204 & 10.333 & 0.043 \\
P25 & 0.027 & 17.209 & 21.424 & 0.315 & 17.505 & 1.010 & 0.000 & 0.014 \\
Median & 0.069 & 17.924 & 22.189 & 0.460 & 18.263 & 1.063 & 15.398 & 0.044 \\
P75 & 0.120 & 18.972 & 23.058 & 0.601 & 19.192 & 1.164 & 18.529 & 0.083 \\
Min & -60.153 & 0.000 & 19.208 & 0.014 & 0.000 & -5.113 & 0.000 & -6.834 \\
Max & 0.983 & 23.007 & 26.748 & 1.952 & 23.915 & 31.662 & 24.094 & 21.172 \\
Std.Dev & 1.637 & 1.867 & 1.371 & 0.202 & 1.782 & 1.056 & 9.074 & 0.638 \\
N & 1410 & 1213 & 1410 & 1410 & 1410 & 1410 & 1410 & 1410 \\
\hline
\end{tabular}

\subsection{Correlation Analysis}

In order to explore the relationship between $\mathrm{R} \& \mathrm{D}$ value and profitability of the explanatory variables, this paper analyzes the Pearson correlation test of the variables involved in the study. It can be seen from Table 4 that the results of Pearson correlation test show that there is a strong correlation between roe and RM. It can be found that the correlation coefficient between R \& D attention (RM) and profit performance (ROE) in this study of Pearson correlation is 0.647 , which is significantly positive correlation at the significance level of 0.01 . It preliminarily tests the relationship between $\mathrm{R} \& \mathrm{D}$ attention and profit performance. At the same time, each control variable in this study maintains a significant correlation with profit performance, which indicates that the selection of variables in this paper is reasonable. 
Table 4. Pearson correlation analysis.

\begin{tabular}{|c|c|c|c|c|c|c|c|c|}
\hline Index & ROE & RM & ASSET & LEV & SR & RCA & GW & SGR \\
\hline ROE & $\begin{array}{c}1.000 * * * \\
(0.000)\end{array}$ & & & & & & & \\
\hline $\mathrm{RM}$ & $\begin{array}{c}0.647^{* * * *} \\
(0.000)\end{array}$ & $\begin{array}{c}1.000^{* * *} \\
(0.000)\end{array}$ & & & & & & \\
\hline ASSET & $\begin{array}{c}0.714^{* * *} \\
(0.000)\end{array}$ & $\begin{array}{c}0.780 * * * \\
(0.000)\end{array}$ & $\begin{array}{c}1.000^{* * *} \\
(0.000)\end{array}$ & & & & & \\
\hline LEV & $\begin{array}{c}0.636^{* * *} \\
(0.000)\end{array}$ & $\begin{array}{c}0.711^{* * *} \\
(0.000)\end{array}$ & $\begin{array}{c}0.843^{* * * *} \\
(0.000)\end{array}$ & $\begin{array}{c}1.000^{* * *} \\
(0.000)\end{array}$ & & & & \\
\hline SR & $\begin{array}{c}0.603^{* * *} \\
(0.000)\end{array}$ & $\begin{array}{c}0.700^{* * *} \\
(0.000)\end{array}$ & $\begin{array}{c}0.791^{* * *} \\
(0.000)\end{array}$ & $\begin{array}{c}0.658^{* * *} \\
(0.000)\end{array}$ & $\begin{array}{c}1.000^{* * *} \\
(0.000)\end{array}$ & & & \\
\hline RCA & $\begin{array}{l}0.101^{* *} \\
(0.025)\end{array}$ & $\begin{array}{l}-0.030 \\
(0.523) \\
\end{array}$ & $\begin{array}{c}0.099 * * \\
(0.028)\end{array}$ & $\begin{array}{c}0.005 \\
(0.913) \\
\end{array}$ & $\begin{array}{c}-0.081 * \\
(0.074)\end{array}$ & $\begin{array}{c}1.000^{* * *} \\
(0.000)\end{array}$ & & \\
\hline GW & $\begin{array}{c}-0.225^{* * *} \\
(0.000)\end{array}$ & $\begin{array}{c}-0.364^{* * *} \\
(0.000)\end{array}$ & $\begin{array}{c}-0.200 * * * \\
(0.000)\end{array}$ & $\begin{array}{c}-0.323^{* * * *} \\
(0.000)\end{array}$ & $\begin{array}{c}-0.349^{* * *} \\
(0.000)\end{array}$ & $\begin{array}{c}0.220 * * * \\
(0.000)\end{array}$ & $\begin{array}{c}1.000^{* * *} \\
(0.000)\end{array}$ & \\
\hline SGR & $\begin{array}{c}0.214^{* * *} \\
(0.000)\end{array}$ & $\begin{array}{c}0.151^{* * *} \\
(0.001)\end{array}$ & $\begin{array}{c}0.151^{* * *} \\
(0.001)\end{array}$ & $\begin{array}{c}0.196^{* * *} \\
(0.000)\end{array}$ & $\begin{array}{c}0.127^{* * *} \\
(0.005)\end{array}$ & $\begin{array}{l}-0.020 \\
(0.661)\end{array}$ & $\begin{array}{c}-0.084 \text { * } \\
(0.062)\end{array}$ & $\begin{array}{c}1.000^{* * *} \\
(0.000)\end{array}$ \\
\hline
\end{tabular}

Note: The parentheses are the values of statistic $p,{ }^{* * *}, * * *{ }^{*}$ indicate significance at $1 \%, 5 \%$ and $10 \%$ confidence levels, respectively.

At the same time, in order to exclude the influence of multicollinearity among variables on the regression results, we do the variance inflation factor (VIF) test in Table 5 and find that the VIF value of each variable is less than 10 , and the overall mean value is 1.44 , which is at a low level, indicating that there is no multicollinearity among variables in this study.

Table 5. Variance inflation factor (VIF) test analysis.

\begin{tabular}{ccc}
\hline Index & VIF & 1/VIF \\
\hline RM & 1.09 & 0.917 \\
ASSET & 2.51 & 0.398 \\
LEV & 1.37 & 0.729 \\
SR & 1.01 & 0.994 \\
RCA & 1.06 & 0.947 \\
GW & 1.15 & 0.866 \\
SGR & 1.01 & 0.994 \\
Mean VIF & 1.44 & \\
\hline
\end{tabular}

\subsection{Basic Regression Analysis}

Table 6 is the basic regression analysis results of this paper. In the basic regression, this paper adopts the method of regression analysis year by year. Firstly, the cross-section data of each year from 2015 to 2019 are regressive to discuss the impact of R \& D investment on profitability in different years. Finally, the panel data are regressive to discuss the relationship between $R$ \& D investment and profitability in the case of full sample. The correlation coefficient between R \& D investment (RM) and profitability effect (ROE) is 0.003 from the sample situation in 2015, indicating that every 1 percentage point increase in $R$ \& D investment will increase the profitability effect by 0.003 percentage points, but this improvement effect is not significant in this year. For 2016 and 2017 data samples, the regression coefficients of the RM and ROE were 0.012 and 0.490 , and the correlation was significant at 0.01 significant level; this also means that with every $1 \%$ increase in RM, ROE will be significantly increased, respectively, in 2016 and 2017, 0.012 and $0.490 \%$, that is to say, R \& D function for the promotion of profit effect is more noticeable in 2016 and 2017.

According to the data of 2018 and 2019, the regression coefficients of RM and ROE are -0.003 and 0.022 , respectively, and the correlation is not significant, which indicates that $R$ 
\& D investment has no positive effect on the profit effect in 2018. Although it has a positive effect in 2019, the effect is not obvious, that is, the promotion of R \& D investment on the profit effect is greatly weakened in 2018 and 2019. Before regressing the panel data, this paper first carried out the BP-LM test and found that the mixed panel effect is better than the random effect. Then, this paper carried out the $\mathrm{F}$ test and found that the mixed panel effect is better than the fixed effect. Therefore, this paper used the mixed panel effect model for panel regression. According to the results of panel regression of the full sample data, on the whole, the regression coefficient between RM and ROE is 0.079 , and this correlation is significant at the significance level of 0.01 , which means that every 1 percentage point increase in RM will significantly increase ROE by 0.0079 percentage points. According to the analysis of resource dependence theory, when the enterprise management attaches great importance to $R \& D$, the enterprise will integrate more resources related to $R \& D$ in decision-making and strategy and create more intangible assets through $R \& D$. this kind of intangible resources will act on the production and operation of the enterprise, improve the operation efficiency and ultimately improve the business performance of the enterprise, thus verifying Hypothesis 1 of this paper. At the same time, all the control variables in this paper are significant on the whole, which indicates that the control variables selected in this paper are reasonable. However, from the perspective of regression fitting, $\mathrm{R}^{2}$ is at a low level, which indicates that the R \& D attention of the power industry and the electrical industry still has a relatively weak impact on the profit performance.

Table 6. Basic regression analysis-year by year analysis.

\begin{tabular}{|c|c|c|c|c|c|c|}
\hline \multirow{2}{*}{ ROE } & \multicolumn{5}{|c|}{ Year } & \multirow{2}{*}{$\begin{array}{c}\text { Panel Regression } \\
2015-2019\end{array}$} \\
\hline & 2015 & 2016 & 2017 & 2018 & 2019 & \\
\hline $\mathrm{RM}$ & $\begin{array}{c}0.003 \\
(0.195)\end{array}$ & $\begin{array}{c}0.012 * * * \\
(0.000)\end{array}$ & $\begin{array}{c}0.490 * * * \\
(0.001)\end{array}$ & $\begin{array}{l}-0.003 \\
(0.711)\end{array}$ & $\begin{array}{c}0.022 \\
(0.167)\end{array}$ & $\begin{array}{c}0.079 * * * \\
(0.003)\end{array}$ \\
\hline ASSET & $\begin{array}{c}0.003 \\
(0.658)\end{array}$ & $\begin{array}{c}0.009 \\
(0.210)\end{array}$ & $\begin{array}{l}1.501^{* * *} \\
(0.000)\end{array}$ & $\begin{array}{l}-0.001 \\
(0.953)\end{array}$ & $\begin{array}{l}0.150^{* * *} \\
(0.000)\end{array}$ & $\begin{array}{l}0.399 * * * \\
(0.000)\end{array}$ \\
\hline LEV & $\begin{array}{l}-0.012 \\
(0.714)\end{array}$ & $\begin{array}{l}-0.033 \\
(0.420)\end{array}$ & $\begin{array}{c}-10.442 * * * \\
(0.000)\end{array}$ & $\begin{array}{l}-0.348^{* * *} \\
(0.000)\end{array}$ & $\begin{array}{l}-1.306^{* * *} \\
(0.000)\end{array}$ & $\begin{array}{l}-3.020 * * * \\
(0.000)\end{array}$ \\
\hline SR & $\begin{array}{c}0.011^{* * *} \\
(0.002)\end{array}$ & $\begin{array}{l}0.009 * * \\
(0.044)\end{array}$ & $\begin{array}{c}-0.453^{* * *} \\
(0.002)\end{array}$ & $\begin{array}{c}0.037^{* * *} \\
(0.001)\end{array}$ & $\begin{array}{l}-0.025 \\
(0.243)\end{array}$ & $\begin{array}{l}-0.104^{* * *} \\
(0.004)\end{array}$ \\
\hline RCA & $\begin{array}{l}0.016 * \\
(0.054)\end{array}$ & $\begin{array}{c}0.003 \\
(0.263)\end{array}$ & $\begin{array}{l}0.663 * \\
(0.097)\end{array}$ & $\begin{array}{c}0.269 * * * \\
(0.000)\end{array}$ & $\begin{array}{l}0.120 * * \\
(0.029)\end{array}$ & $\begin{array}{c}0.036 \\
(0.405)\end{array}$ \\
\hline GW & $\begin{array}{c}0.000 \\
(0.451)\end{array}$ & $\begin{array}{l}-0.001 \\
(0.111)\end{array}$ & $\begin{array}{c}-0.045^{*} \\
(0.062)\end{array}$ & $\begin{array}{l}-0.003 \\
(0.107)\end{array}$ & $\begin{array}{l}-0.003 \\
(0.385)\end{array}$ & $\begin{array}{l}-0.010 * \\
(0.089)\end{array}$ \\
\hline CONS & $\begin{array}{c}-0.243 \text { ** } \\
(0.022)\end{array}$ & $\begin{array}{c}-0.470 * * * \\
(0.001)\end{array}$ & $\begin{array}{c}-29.957^{* * *} \\
(0.000)\end{array}$ & $\begin{array}{c}-0.687^{* *} \\
(0.014)\end{array}$ & $\begin{array}{c}-2.765^{* * *} \\
(0.000)\end{array}$ & $\begin{array}{c}-7.005^{* * *} \\
(0.000)\end{array}$ \\
\hline Obs & 206 & 218 & 247 & 261 & 281 & 1213 \\
\hline R-squared & 0.11 & 0.13 & 0.37 & 0.30 & 0.31 & 0.21 \\
\hline
\end{tabular}

Note: The parentheses are the values of statistic $p,{ }^{* * *}, * *, *$ indicate significance at $1 \%, 5 \%$ and $10 \%$ confidence levels, respectively.

\subsection{Further Study}

In the further research, this paper conducts group research on property right nature and the division of electric power industry and electrical industry, in order to further explore the influence of R \& D attention on profitability. In the grouping of property right structure, the whole sample is divided into state-owned enterprises and private enterprises according to the property right structure, and the state-owned enterprises are further divided into three groups according to the level of national state-owned enterprises and central enterprises, provincial and municipal state-owned enterprises and all samples of state-owned enterprises for regression. 
Table 7 shows the regression results of property right structure grouping, and the samples of state-owned enterprises and private enterprises draw different experimental conclusions. About the national and central enterprises, provincial and municipal stateowned enterprises, the overall data samples, the regression coefficient of the RM and ROE are, respectively, $-0.002,0.004,0.003$, and the correlations are not significant. It shows that the effect of R \& D attention on the profitability of state-owned enterprises is not obvious and even has a negative impact on the profitability of national and central enterprises, which may be related to the relatively strict hierarchical organizational structure of stateowned enterprises. In private enterprises, the RM with ROE regression coefficient was 0.140 , and the correlation significant is at 0.01 significant level; this also means that, RM of private enterprises increases every $1 \%$; ROE will be significantly increased by $0.140 \%$, that is to say, R \& D function for the promotion of profit effect in the private electric power and electrical enterprises is more noticeable. In this paper, the research hypothesis 2 is verified.

Table 7. Further study-property nature group.

\begin{tabular}{|c|c|c|c|c|}
\hline \multirow{2}{*}{ ROE } & \multicolumn{3}{|c|}{ State-Owned Enterprises } & \multirow{2}{*}{ Private Enterprises } \\
\hline & National \& Central & Provincial and Municipal & Overall & \\
\hline $\mathrm{RM}$ & $\begin{array}{l}-0.002 \\
(0.626)\end{array}$ & $\begin{array}{c}0.004 \\
(0.905)\end{array}$ & $\begin{array}{c}0.003 \\
(0.781)\end{array}$ & $\begin{array}{c}0.140 * * * \\
(0.001)\end{array}$ \\
\hline ASSET & $\begin{array}{c}0.013^{* * *} \\
(0.414)\end{array}$ & $\begin{array}{c}0.451^{* * *} \\
(0.000)\end{array}$ & $\begin{array}{c}0.279 * * * \\
(0.000)\end{array}$ & $\begin{array}{c}0.438^{* * *} \\
(0.000)\end{array}$ \\
\hline LEV & $\begin{array}{c}-0.203^{* *} \\
(0.015)\end{array}$ & $\begin{array}{c}-2.791 * * * \\
(0.000)\end{array}$ & $\begin{array}{c}-1.825^{* * *} \\
(0.000)\end{array}$ & $\begin{array}{c}-3.736^{* * *} \\
(0.000)\end{array}$ \\
\hline SR & $\begin{array}{c}0.010 \\
(0.474)\end{array}$ & $\begin{array}{c}-0.257 * * * \\
(0.003)\end{array}$ & $\begin{array}{c}-0.154^{* * *} \\
(0.001)\end{array}$ & $\begin{array}{c}-0.104^{* *} \\
(0.015)\end{array}$ \\
\hline RCA & $\begin{array}{l}0.110 * \\
(0.068)\end{array}$ & $\begin{array}{l}-0.127 \\
(0.164)\end{array}$ & $\begin{array}{l}-0.002 \\
(0.978)\end{array}$ & $\begin{array}{c}0.033 \\
(0.505)\end{array}$ \\
\hline GW & $\begin{array}{c}0.000 \\
(0.972)\end{array}$ & $\begin{array}{c}0.011 \\
(0.194)\end{array}$ & $\begin{array}{c}0.006 \\
(0.145)\end{array}$ & $\begin{array}{c}-0.014 \text { * } \\
(0.054)\end{array}$ \\
\hline CONS & $\begin{array}{c}-0.422 \text { ** } \\
(0.036)\end{array}$ & $\begin{array}{c}-3.983^{* * *} \\
(0.008)\end{array}$ & $\begin{array}{c}-2.593^{* * *} \\
(0.000)\end{array}$ & $\begin{array}{c}-8.644^{* * *} \\
(0.000)\end{array}$ \\
\hline Obs & 131 & 127 & 258 & 955 \\
\hline R-squared & 0.18 & 0.48 & 0.29 & 0.23 \\
\hline
\end{tabular}

Note: The parentheses are the values of statistic $p,{ }^{* * *}, * *,{ }^{*}$ indicate significance at $1 \%, 5 \%$ and $10 \%$ confidence levels, respectively.

In the division of industry nature, this paper divides enterprises into the electric power industry and the electrical industry. Meanwhile, according to the characteristics of declining promotion of R \& D in 2018-2019 existing in the basic regression, on the basis of the industry division, the regression is conducted into stage 1 (2015-2017), stage 2 (2018-2019) and whole stage (2015-2019), respectively.

Table 8 shows the regression results of power and electrical industry groups, and the regression results of power industry and electrical industry enterprise samples are also quite different. For power enterprises, the regression coefficient of RM and roe in the whole stage is -0.002 , which is not significant, indicating that $R \&$ D attention cannot significantly improve the profitability of power enterprises or even reduce the profitability to a certain extent, and this reduction effect is larger in stage 1 (the regression coefficient is -0.003). However, with the gradual progress of power enterprise reform and other programs, the regression coefficient of RM and roe in stage 2 turns from negative to positive, which is 0.002 , indicating that the role of $\mathrm{R} \& \mathrm{D}$ emphasis in improving profitability of power enterprises begins to reflect. In the electrical industry, the regression coefficients of RM and roe are $0.661,0.053$ and 0.382 for the data samples of stage 1 , stage 2 and the whole stage, respectively, and the correlations are significant at the significance level of $0.01,0.05$ 
and 0.01 , which indicates that $\mathrm{R} \& \mathrm{D}$ attention in each stage can significantly improve the profitability of the electrical industry. Hypothesis 3 of this paper is verified.

Although the $\mathrm{R} \& \mathrm{D}$ attention of the electrical industry in each stage has a positive impact on the profit performance, comparing the regression coefficient and significance, we can find that the regression coefficient and significance in the second stage are significantly lower than those in the first stage. This shows that the electrical industry should continue to improve the corporate structure, optimize corporate governance, continue to deepen the development of $\mathrm{R} \& \mathrm{D}$ and attach great importance to the positive impact on corporate profitability.

Table 8. Further Study—-power and electrical industries group.

\begin{tabular}{|c|c|c|c|c|c|c|}
\hline \multirow{2}{*}{ ROE } & \multicolumn{3}{|c|}{ The Electric Power Industry } & \multicolumn{3}{|c|}{ The Electrical Industry } \\
\hline & 2015-2017 & 2018-2019 & 2015-2019 & 2015-2017 & 2018-2019 & 2015-2019 \\
\hline $\mathrm{RM}$ & $\begin{array}{l}-0.003 \\
(0.262)\end{array}$ & $\begin{array}{c}0.002 \\
(0.318)\end{array}$ & $\begin{array}{l}-0.002 \\
(0.220)\end{array}$ & $\begin{array}{c}0.661^{* * *} \\
(0.000)\end{array}$ & $\begin{array}{l}0.053 * * \\
(0.037)\end{array}$ & $\begin{array}{l}0.382 * * * \\
(0.000)\end{array}$ \\
\hline ASSET & $\begin{array}{l}-0.001 \\
(0.955)\end{array}$ & $\begin{array}{l}-0.002 \\
(0.855)\end{array}$ & $\begin{array}{c}-0.008 \\
(0.571)\end{array}$ & $\begin{array}{c}0.372 * * \\
(0.020)\end{array}$ & $\begin{array}{c}0.046 \\
(0.156)\end{array}$ & $\begin{array}{l}0.157 * \\
(0.094)\end{array}$ \\
\hline LEV & $\begin{array}{c}-0.215 \text { * } \\
(0.055)\end{array}$ & $\begin{array}{c}-0.109 \\
(0.164) \\
\end{array}$ & $\begin{array}{c}-0.122 \\
(0.121)\end{array}$ & $\begin{array}{c}-6.113^{* * *} \\
(0.000)\end{array}$ & $\begin{array}{c}-0.861^{* * * *} \\
(0.000)\end{array}$ & $\begin{array}{c}-3.267^{* * *} \\
(0.000)\end{array}$ \\
\hline SR & $\begin{array}{c}0.016 \\
(0.254) \\
\end{array}$ & $\begin{array}{c}0.004 \\
(0.675) \\
\end{array}$ & $\begin{array}{c}0.014 \\
(0.169) \\
\end{array}$ & $\begin{array}{c}-0.233^{* * *} \\
(0.001)\end{array}$ & $\begin{array}{c}0.009 \\
(0.543) \\
\end{array}$ & $\begin{array}{c}-0.129 * * * \\
(0.001)\end{array}$ \\
\hline RCA & $\begin{array}{c}0.084^{* *} \\
(0.019)\end{array}$ & $\begin{array}{c}0.319^{* * *} \\
(0.000)\end{array}$ & $\begin{array}{c}0.074^{* * *} \\
(0.004)\end{array}$ & $\begin{array}{c}0.040 \\
(0.521)\end{array}$ & $\begin{array}{c}0.192 * * * \\
(0.000)\end{array}$ & $\begin{array}{c}0.045 \\
(0.332)\end{array}$ \\
\hline GW & $\begin{array}{l}-0.001 \\
(0.451)\end{array}$ & $\begin{array}{c}-0.002 \text { ** } \\
(0.041)\end{array}$ & $\begin{array}{l}-0.001 \\
(0.239)\end{array}$ & $\begin{array}{c}-0.021 \text { * } \\
(0.066)\end{array}$ & $\begin{array}{c}-0.004 \text { * } \\
(0.070)\end{array}$ & $\begin{array}{c}-0.013^{* *} \\
(0.047)\end{array}$ \\
\hline CONS & $\begin{array}{l}-0.130 \\
(0.550)\end{array}$ & $\begin{array}{c}-0.242 * \\
(0.091)\end{array}$ & $\begin{array}{c}0.031 \\
(0.844)\end{array}$ & $\begin{array}{c}-13.302^{* * *} \\
(0.000)\end{array}$ & $\begin{array}{c}-1.923 * * * \\
(0.000)\end{array}$ & $\begin{array}{c}-6.619 * * * \\
(0.000)\end{array}$ \\
\hline Obs & 79 & 76 & 155 & 592 & 466 & 1058 \\
\hline R-squared & 0.34 & 0.40 & 0.29 & 0.22 & 0.28 & 0.32 \\
\hline
\end{tabular}

Note: The parentheses are the values of statistic $p^{* * *}, * *, *$ indicate significance at $1 \%, 5 \%$ and $10 \%$ confidence levels, respectively.

\subsection{Robustness Test}

In order to test the accuracy and universality of the empirical regression conclusion, this paper adopts the robustness test method of variable replacement and model replacement. In the first part of the robustness test, this paper carries out the replacement (ROA) of the explained variables and the regression of the added test variables (business sustainability). In the second part of the robustness test, this paper discusses the universality of the empirical model and uses logit and probit models to carry out the regression verification.

Table 9 shows the regression results of the robustness test for the replacement variables. After the explanatory variable ROE is replaced by ROA, the regression results show that the regression coefficient of RM and ROA is 0.004 , and it is significant at the significance level of 0.01 , indicating that $\mathrm{R} \& \mathrm{D}$ attention can significantly improve the profitability of the electric power industry and electrical industry, and this promotion effect is still significant after the explanatory variable is replaced. As a powerful guarantee of technological wealth and a strategic investment of enterprises, $R$ \& D investment often cannot act on the profit return of enterprises in the short term. Considering that the promotion of $\mathrm{R} \& \mathrm{D}$ emphasis on profitability may be affected by business continuity, this paper adds business continuity into the robustness test. The results show that the regression coefficient of RM and ROA is 0.078 after considering the business sustainability, which is significant at the significance level of 0.01 , indicating that $R \& D$ attention can significantly improve the profitability of the power and electrical industry, and the regression coefficient of R \& D attention (SGR) and $\mathrm{ROE}$ is 0.333 , which is positively correlated at the significance level of 0.01 . It shows 
that business sustainability can indeed improve the overall profitability of enterprises, and the experimental results of this paper are still robust.

Table 9. Robustness test-substitution of variables.

\begin{tabular}{ccc}
\hline & $\mathbf{( 1 )}$ & $\mathbf{( 2 )}$ \\
\cline { 2 - 3 } & ROA & ROE \\
\hline \multirow{2}{*}{ RM } & $0.004^{* * *}$ & $0.078^{* * *}$ \\
& $(0.007)$ & $(0.003)$ \\
\hline \multirow{2}{*}{ ASSET } & $0.021^{* * *}$ & $0.411^{* * *}$ \\
& $(0.000)$ & $(0.000)$ \\
\hline \multirow{2}{*}{ LEV } & $-0.268^{* * *}$ & $-3.048^{* * *}$ \\
SR & $(0.000)$ & $(0.000)$ \\
\hline \multirow{2}{*}{ RCA } & $0.005^{* *}$ & $-0.110^{* * *}$ \\
& $(0.019)$ & $(0.002)$ \\
\hline \multirow{2}{*}{ GW } & $0.010^{* * *}$ & 0.025 \\
& $(0.000)$ & $(0.559)$ \\
\hline \multirow{2}{*}{ SGR } & $-0.001^{* * *}$ & -0.009 \\
& $(0.000)$ & $(0.111)$ \\
\hline \multirow{2}{*}{ CONS } & & $0.333^{* * *}$ \\
& & $(0.000)$ \\
\hline Obs & $-0.479^{* * *}$ & $-7.131^{* * *}$ \\
\hline Rquared & $(0.000)$ & $(0.000)$ \\
\hline Note & 1213 & 1213 \\
\hline
\end{tabular}

Note: The parentheses are the values of statistic $p,{ }^{* * *},{ }^{* *}$, indicate significance at $1 \%$ and $5 \%$ confidence levels, respectively.

Table 10 shows the regression results of robustness test-model replacement. In this paper, the explained variable ROE was re-measured and divided from the original sequence data into $0-1$ classified data for regression, so as to test the model applicability of the research results in this paper. After regression by probit model, the regression results show that the regression coefficient of RM and ROA is 0.127 , which is significant at the significance level of 0.01 , indicating that the degree of research and development attention can significantly improve the profit effect of the electric power industry, and this improvement effect is still significant after the adoption of the probit model. Logit model was used for regression, and the regression results showed that the regression coefficient of $\mathrm{RM}$ and ROA was 0.307 , which was significant at the significance level of 0.01 , indicating that the degree of research and development attention could significantly improve the profitability of the power and electrical industries, and this improvement effect was still significant after Logit model was adopted. Therefore, the empirical research conclusions of this paper are still consistent with the basic regression after using the two classified regression models, and the experimental results of this paper are still robust. 
Table 10. Robustness test-model replacement.

\begin{tabular}{ccc}
\hline \multirow{2}{*}{ ROE1 } & $\mathbf{( 1 )}$ & $\mathbf{( 2 )}$ \\
\cline { 2 - 3 } & PROBIT & LOGIT \\
\cline { 2 - 3 } RM & $0.127^{* * *}$ & $0.307^{* * *}$ \\
& $(0.000)$ & $(0.000)$ \\
\hline \multirow{2}{*}{ ASSET } & $-0.272^{* * *}$ & $-0.578^{* * *}$ \\
& $(0.000)$ & $(0.000)$ \\
\hline \multirow{2}{*}{ LEV } & -0.212 & -0.107 \\
& $(0.459)$ & $(0.831)$ \\
\hline \multirow{2}{*}{ SR } & $0.404^{* * * *}$ & $0.739^{* * *}$ \\
& $(0.000)$ & $(0.000)$ \\
\hline \multirow{2}{*}{ RCA } & $0.369^{* * *}$ & $0.874^{* * *}$ \\
& $(0.000)$ & $(0.000)$ \\
\hline \multirow{2}{*}{ GW } & $-0.020^{* * *}$ & $-0.035^{* * *}$ \\
& $(0.000)$ & $(0.000)$ \\
\hline \multirow{2}{*}{ CONS } & $-4.507^{* * *}$ & $-8.085^{* * *}$ \\
& $(0.000)$ & $(0.000)$ \\
\hline Obs & 1213 & 1213 \\
\hline R-squared & 0.11 & 0.11 \\
\hline Note: The parentheses are the values of statistic $p_{* * * *}^{*}$ indicate significance at $1 \%$. &
\end{tabular}

\section{Conclusions}

Based on the samples of listed companies in China's power industry and electrical industry from 2015 to 2019, this paper empirically studies the relationship between R \& D attention and corporate earnings performance in the power and electrical industries. We get the following conclusions: first, there is a strong correlation between $\mathrm{R} \& \mathrm{D}$ attention and profit performance in China's power industry and electrical industry, but on the whole, the fitting degree and intensity of $\mathrm{R} \& \mathrm{D}$ attention to profit performance are relatively low. $\mathrm{R} \& \mathrm{D}$ attention by power industry and electrical industry companies will improve the profitability of enterprises, and this effect has year heterogeneity. From 2015 to 2017, R \& D attention gradually improved the profitability of enterprises, but the profitability generated by $R$ \& D investment in recent years is insufficient, which needs further attention and improvement; second, compared with the state-owned enterprises, the R \& D attention has a significant effect on the corporate profitability in the private enterprise group. The $\mathrm{R} \&$ $\mathrm{D}$ attention of the national and central enterprises in the power and electrical industries cannot significantly improve the corporate profitability and even has a negative effect on the national enterprises and central enterprises; third, compared with the power industry, $\mathrm{R}$ \& D investment in the electrical industry can significantly improve the profit performance, but the ability and effect of this significant improvement are relatively slow in recent years. The significant improvement effect of $\mathrm{R} \& \mathrm{D}$ investment on the profit effect of listed companies in the power industry has not been reflected, but it shows a steady improvement trend in recent years.

Electric power industry and electrical industry are the basic industries and strategic emerging industries in China's national economy. In order to enhance the importance of industrial R \& D and then improve the performance of industrial profitability, China's R \& $D$ departments should optimize the efficiency of $R$ \& $D$ investment and pay attention to the R \& D structure adjustment. The economic consequences of $R$ \& D innovation have a long-term nature. Enterprises should take R \& D innovation as a long-term and sustainable strategic task, continuously enhance the emphasis on R \& D and then continuously obtain the economic dividend brought by R \& D. From the perspective of property right structure, China's state-owned enterprises should further improve the equity structure and governance structure, gradually absorb private capital, promote the R \& D attention of 
state-owned enterprises, especially China's national enterprises and central enterprises and inject vitality into the technological innovation of enterprises. From the perspective of industry structure, China's electrical industry should continue to maintain the level of R \& D investment, further strengthen corporate governance, solve the problems existing in R \& $\mathrm{D}$ structure and continue to maintain the role of $\mathrm{R} \& \mathrm{D}$ attention in improving enterprise performance. The power industry should increase the investment in independent $R \& D$, pay attention to the utilization rate of $\mathrm{R} \& \mathrm{D}$ investment, especially encourage China's large power state-owned enterprises and central enterprises to make breakthroughs in key technologies and improve the innovation ability and the spillover effect of $\mathrm{R} \& \mathrm{D}$ on profit performance. China's R \& D departments should give full play to the capital scale advantages of state-owned enterprises according to different property rights, combine the vitality of private capital and enhance the $R \& D$ performance spillover capacity of enterprises. In addition, China's R \& D policy departments should consider the R \& D heterogeneity of different industries, give support to key technologies and promote scientific and technological innovation on important issues and then bring about the improvement of enterprise performance.

Author Contributions: Y.S. completed the conception, design and empirical research of the paper, S.J. completed the writing of the introduction, literature and conclusion, and Y.L. proofread the whole paper. All authors have read and agreed to the published version of the manuscript.

Funding: This research was funded by the Technology Projects of China State Grid Corporation (5102-201956301A-0-0-00).

Institutional Review Board Statement: Not applicable.

Informed Consent Statement: Not applicable.

Data Availability Statement: Not applicable.

Conflicts of Interest: The authors declare no conflict of interest.

\section{References}

1. Guo, F.; Bo, Q.; Tong, X.; Zhang, X. A paradoxical view of speed and quality on operational outcome: An empirical investigation of innovation in high-tech small and medium-sized enterprises. Int. J. Prod. Econ. 2020, 229, 107780. [CrossRef]

2. Xu, J.; Wang, X.; Liu, F. Government subsidies, R\&Dinvestment and innovation performance: Analysis from pharmaceutical sector in China. Technol. Anal. Strateg. Manag. 2020, 33, 535-553.

3. Yang, H.K.; Yang, H.S.; Song, W.K. Analysis of the Effectiveness of Government's SME R\&DSubsidies: Focusing on Information and Communications Technology (ICT) Industry. J. Korean Oper. Res. Manag. Sci. Soc. 2019, 44, 31-44.

4. Tebourbi, I.; Ting, I.W.K.; Le, H.T.M.; Kweh, Q.L. R\&Dinvestment and future firm performance: The role of managerial overconfidence and government ownership. Manag. Decis. Econ. 2020, 41, 1269-1281.

5. Wu, C.P.; Tang, D. Enforcement of intellectual property protection, technological innovation and enterprise performanceEvidence from Chinese Listed Companies. Econ. Res. 2016, 51, 125-139.

6. Aboody, D.; Lev, B. The Value-Relevance of Intangibles: The Case of Software Capitalization. J. Account. Res. 1998, 3, 161-204. [CrossRef]

7. Edward, B.; Roberts, A. Technology, innovation and competitive advantage. Mak. Innov. Manag. 1995, 5, 351-376.

8. Lee, H.Y. Corporate Performance and R\&DInvestment. Korean J. Bus. Adm. 2017, 30, 1-20.

9. Piga, C.; Vivarelli, M. Sample selection in estimating the determinants of cooperative R\&D. Appl. Econ. Lett. 2003, 1, $243-246$.

10. Woo, J.; Hong, A. A Study on the Impact of SME R\&DOrganization and Investment on Corporate Performance. Innov. Stud. 2020, 15, 197-229.

11. Brown, M.G.; Svenson, R.A. Measuring R\&Dproductivity. Res. Technol. Manag. 1998, 2, 30-35.

12. Teirlinck, P. Configurations of strategic R\&Ddecisions and financial performance in small-sized and medium-sized firms. J. Bus. Res. 2017, 74, 55-65.

13. Lee, Y.; Kim, S.; Lee, H. The impact of service R\&Don the performance of Korean information communication technology small and medium enterprises. J. Eng. Technol. Manag. 2011, 28, 77-92.

14. Sohn, D.W.; Hur, W.; Kim, H.J. Effects of R\&Dand Patents on the Financial Performance of Korean Venture Firms. Asian J. Technol. Innov. 2010, 18, 169-185.

15. Alam, M.S.; Atif, M.; Chien-Chi, C.; Soytaş, U. Does corporate R\&Dinvestment affect firm environmental performance? Evidence from G-6 countries. Energy Econ. 2019, 78, 401-411. 
16. Lee, K.H.; Min, B. Green R\&Dfor eco-innovation and its impact on carbon emissions and firm performance. J. Clean. Prod. 2015, $108,534-542$.

17. Bernile, G.; Bhagwat, V.; Yonker, S. Board diversity, firm risk, and corporate policies. J. Financ. Econ. 2016, 127, 588-612. [CrossRef]

18. Baumann, J.; Kritikos, A.S. The link between R\&D, innovation and productivity: Are micro firms different? Res. Policy 2016, 45, 1263-1274.

19. Yigitcanlar, T.; Sabatini-Marques, J.; da-Costa, E.M.; Kamruzzaman, M.; Ioppolo, G. Stimulating technological innovation through incentives: Perceptions of Australian and Brazilian firms. Technol. Forecast. Soc. Chang. 2017, 146, 403-412. [CrossRef]

20. Song, M.; Wang, S.; Sun, J. Environmental regulations, staff quality, green technology, R\&Defficiency, and profit in manufacturing. Technol. Forecast. Soc. Chang. 2018, 133, 1-14.

21. Ferraris, A.; Santoro, G.; Dezi, L. How MNC's subsidiaries may improve their innovative performance? The role of external sources and knowledge management capabilities. J. Knowl. Manag. 1997. [CrossRef]

22. Megginson, W.L.; Netter, J.M. From State to Market: A Survey of Empirical Studies on Privatization. J. Econ. Lit. 2001, 39, 321-389. [CrossRef]

23. Li, Y.; Lee, J. R\&DInvestment and Stock Returns: Evidence from China. J. Korean Data Anal. Soc. 2019, 21, 1705-1720.

24. Saffar, C.W. The role of state and foreign owners in corporate risk-taking: Evidence from privatization. J. Financ. Econ. 2013, 108, 641-658.

25. Chen, X.; Xie, E.; Van Essen, M. Performance feedback and firms' R\&Dfrequency: A comparison between state-owned and private-owned enterprises in China. Asian Bus. Manag. 2021, 20, 221-258.

26. Han, X.; Hus, S.; Li, J. The Impact of Enterprises' Shadow Banking Activities on Business Performance: A Test Based on Mediator Effect of Investment Scale and Investment Efficiency. Emerg. Mark. Financ. Trade 2019, 55, 3258-3274. [CrossRef]

27. Jia, Z.; Lin, B. The impact of removing cross subsidies in electric power industry in China: Welfare, economy, and $\mathrm{CO}_{2}$ emission. Energy Policy 2021, 148, 111994. [CrossRef]

28. Oh, S. The Eco-efficiency Analysis of Power Generation Companies in Korea: Using Data Envelopment Analysis. Korean Policy Sci. Rev. 2019, 23, 59-86. [CrossRef]

29. Stefko, R.; Jencova, S.; Vasanicova, P.; Litavcova, E. An Evaluation of Financial Health in the Electrical Engineering Industry. J. Compet. 2019, 11, 144-160. [CrossRef]

30. Sellitto, M.A.; Hermann, F.F. Influence of Green Practices on Organizational Competitiveness: A Study of the Electrical and Electronics Industry. Eng. Manag. J. 2019, 31, 98-112. [CrossRef]

31. He, P.L.; Sun, Y.L.; Li, T.; Yuan, Y.; Chen, Y.R. Directors' Characteristics and Business Performance: An Empirical Study Based on China's New Third Board Enterprises. Account. Res. 2019, 385, 49-55.

32. Zhang, B.Z.; Lu, J. Can Replacing Business Tax with Value-Added Tax Improve the R\&DInvestment of Listed Companies-Based on Empirical Analysis of Innovative Pilot Enterprises in Shanghai and Shenzhen Stock Exchanges. J. Account. 2015, 27-31. [CrossRef]

33. Liu, X.; Xue, Y.Z. CEO succession, performance deviation and firm R\&Dinvestment: A perspective on the direction of strategic change. Nankai Bus. Rev. 2015, 18, 34-47.

34. Xu, W.X.; Huang, M.J.; Li, L.; Zhong, Q. The Impact of Financial Subsidies and R\&Don Firm Innovation Performance. East China Econ. Manag. 2018, 32, 129-134. 